\title{
Source rocks sedimentary environment and hydrocarbon generating potential of the lower Cambrian in Kalpin thrust belt
}

ZHNEGHUI,WU ${ }^{1}$ HONGKUN WANG ${ }^{2}$,XIUXIANG LV ${ }^{3}$

${ }^{1}$ State Key Laboratory of Petroleum Resources and Prospecting, China University of Petroleum (Beijing), Beijing 102249, China 1513514071@qq.com

${ }^{2}$ State Key Laboratory of Petroleum Resources and Prospecting, China University of Petroleum (Beijing), Beijing 102249, China 3288462832@qq.com

${ }^{3}$ State Key Laboratory of Petroleum Resources and Prospecting, China University of Petroleum (Beijing), Beijing 102249, China 2836459002@qq.com

The organic geochemistry and inorganic geochemistry were combined to study the paleoenvironment and hydrocarbon generation potential of the lower Cambrian source rocks in Kalpin thrust belt.

The conclusions obtained are as follows: (1) After transgression and regression, the paleoenvironment of the Yuertus Formation is mainly the anoxic marine saltwater environment with gradually dry and hot climate and high paleoproductivity;(2)The source rocks of the Lower Cambrian Yuertus Formation in the study area are mainly black carbonaceous shale and dark grey argillaceous dolomite, with thin sedimentary thickness, but high total organic carbon content, and most of them meet the criteria of good hydrocarbon source rocks; (3) The organic matter types of Yuertus Formation in this area are classified by carbon isotope and the ratio of pristine to phytane, and the organic matter types of Yuertus Formation in this area are mainly type I and type II in some areas (possibly affected by weathering); (4) There are two sources of hydrocarbongenerating parent material in Yuertus Formation. The bottom is mainly benthic organisms, and gradually becomes planktonic algae upward. These are consistent with the indication of $\left(\mathrm{nC}_{21}+\mathrm{nC}_{22}\right) /\left(\mathrm{nC}_{28}+\mathrm{nC}_{29}\right)$, which shows that the Yuertus Formation has strong hydrocarbon generating capacity and good hydrocarbon generating potential. 